ISSN : 2354 - 6034 (Print)

ISSN : 2599 - 0187 (Online)

\title{
DAMPAK ALIH FUNGSI PERKEBUNAN KARET KE KELAPA SAWIT BAGI KESEJAHTERAAN PETANI DESA KEBUN AGUNG KECAMATAN PANGKALAN BANTENG KABUPATEN KOTAWARINGIN BARAT
}

\author{
Khabib Mustofa \\ Praktisi Perbankan Syariah \\ Email: khabibmusthofa1996@gmail.com
}

\begin{abstract}
This research is a phenomenon of the function of rubber to oil palm plantations carried out by farmers in the village of Kebun Agung, Pangkalan Banteng District, Kotawaringin Barat Regency. The aims of this study how the background causes of rubber farmers to switch to being an oil palm farmer in Kebun Agung Village. Second, how is the impact on the welfare of rubber farmers after being converted into oil palm farmers in Kebun Agung Village. The purpose of this study is to find out the background that causes rubber farmers to convert their plantations into oil palms and the impact on the welfare of farmers. This research is a qualitative research with a descriptive approach. The subject was focused on 9 farmers by sampling using purposive sampling techniques.

The results of this study indicate that the background of the cause of rubber farmers to switch to being an oil palm farmer in Kebun Agung Village, Pangkalan Banteng District, Kotawaringin Barat Regency is work as a rubber farmer that is done every day while the price is cheap so that farmers' income is not enough to meet economic needs. Whereas palm oil works only once every two weeks are more expensive than rubber and are sufficient to meet daily needs. The impact of the welfare of the rubber farmer's family after being converted into an oil palm farmer in Kebun Agung Village, Pangkalan Banteng District, Kotawaringin Barat Regency is a positive impact for farmers, their income increases, their work is lighter, their assets are increased, and their families feel more prosperous than before.
\end{abstract}




\begin{abstract}
ABSTRAK
Penelitian ini adalah fenomena alih fungsi perkebunan karet ke kelapa sawit yang dilakukan petani desa Kebun Agung Kecamatan Pangkalan Banteng Kabupaten Kotawaringin Barat. Fokus masalah pada penelitian ini adalah bagaimana latar belakang penyebab petani karet beralih fungsi menjadi petani kelapa sawit di Desa Kebun Agung. Kedua, bagaimana dampak bagi kesejahteraan petani karet setelah alih fungsi menjadi petani kelapa sawit Desa Kebun Agung.Tujuan dari penelitian ini adalah untuk mengetahui latar belakang yang menyebabkan petani karet mengalihfungsikan kebunnya menjadi kelapa sawit dan dampak bagi kesejahteraan petani. penelitian ini adalah penelitian kualitatif dengan pendekatan deskriptif. Subjeknya difokuskan pada 9 petani dengan pengambilan sampel menggunakan teknik purposive sampling.

Hasil penelitian ini menunjukan bahwa latar belakang penyebab petani karet beralih fungsi menjadi petani kelapa sawit di Desa Kebun Agung Kecamatan Pangkalan Banteng Kabupaten Kotawaringin Barat adalah pekerjaan sebagai petani karet yang dilakukan setiap hari sedangkan harganya murah sehingga pendapatan petani tidak cukup untuk memenuhi kebutuhan ekonomi. Sedangkan pekerjaan kelapa sawit hanya dua minggu sekali harganya lebih mahal dibandingkan karet dan cukup untuk memenuhi kebutuhan sehari-hari. Dampak kesejahteraan keluarga petani karet setelah alih fungsi menjadi petani kelapa sawit Desa Kebun Agung Kecamatan Pangkalan Banteng Kabupaten Kotawaringin Barat adalah berdampak positif bagi petani, pendapatan mereka meningkat, pekerjaan lebih ringan, adanya peningkatan aset yang dimiliki, dan keluarga lebih merasa sejahtera dari sebelumnya. Kata Kunci: Dampak, Alih Fungsi, Perkebunan, Karet, Kelapa Sawit
\end{abstract}

\title{
PENDAHULUAN
}

Komoditas pertanian yang termasuk ramai ditekuni di Kalimantan adalah karet. Karet, dapat mudah berkembang di Kalimantan karena faktor tanah yang cocok kemudian terdapat 2 pabrik karet, pertama di Kabupaten Kotawaringin Timur dan di Kabupaten Barito Selatan dan akan bertambah 2 lagi di Gunung Mas dan Pulang Pisau. ${ }^{1}$ Bertani karet banyak diminati karena umurnya yang panjang, sehingga walaupun harga fluktuatif petani bakal mempertahankan karetnya tersebut, selain itu perawatannya yang mudah dan murah sehingga banyak orang yang menekuni hal tersebut.

Masyarakat desa dalam kehidupan sehari-hari menggantungkan pada alam. Karena alam memberikan apa yang dibutuhkan mereka bagi kehidupannya. Seperti diketahui masyarakat pedesaan sering diidentikkan dengan masyarakat agraris yaitu masyarakat yang kegiatan ekonominya terpusat pada pertanian maka dengan bekerja disektor pertanian

\footnotetext{
${ }^{1}$ Tempo.Com 21 September 2007.
} 


\section{Khabib Mustofa}

masyarakat pedesaan berusaha meningkatkan pendapatan dan kesejahteraan.

Terkait dengan kehidupan masyarakat desa dan hasil perkebunannya, Di desa Kebun Agung, Kecamatan Pangkalan Banteng, Kabupaten Kotawaringin Barat, pada awal mulanya mayoritas petani karet yang membuat mereka sejahtera, bahkan sebagai suatu usaha yang menjanjkan yang kala itu sempat menyentuh lebih dari harga 15.000/ kilogramnya, dengan rata-rata petani sekali panen kurang lebih satu kuintal dalam kurun waktu yang kurang lebih dua minggu, sehingga di daerah ini didominasi oleh komoditas karet bahkan menjadi salah satu wilayah pola perkebunan PIR yang sudah menjadi kebijakan pemerintah.

Pada tahun 1992 masuk investor PT. Indoturba Tengah yang mendirikan pabrik kelapa sawit di daerah Amin Jaya Kabupaten Kotawaringin Barat, kemudian PT. Astra Agro Lestari, Tbk pada tahun 1993. ${ }^{2}$ Dimana PT. Astra Agro Lestari ini secara letak geografis berdampingan dengan desa Kebun Agung. Keberadaan PT. Indoturba ini cukup berpengaruh kepada pola pikir masyarakat yang pada awalnya membudidayakan perkebunan karet menjadi perkebunan kelapa sawit, bahkan ada yang berinisiatif membuka lahan baru untuk ditanami sawit meskipun ada yang sudah ditanami pohon karet kemudian ditebang dan diganti dengan kelapa sawit. Hal tersebut peneliti ketahui berawal dari informasi masyarakat dan dari pengamatan.

Observasi awal diketahui penghasilan petani tergantung luas lahan dan harga barang produksi petani. Petani Desa Kebun Agung dengan 2 hektar lahan karet dan 2 kali dalam sebulan, rata-rata sekali panen $100 \mathrm{~kg} / 1 \mathrm{kuintal}$, dengan harga jual 6500 di bulan september 2016 didaerah tersebut. Secara otamatis petani karet mendapatkan 650.000 rupiah per sekali paen dan akan mendapatkan 1.300.000/2 hektar laha n per bulan. Sedangkan petani kelapa sawit dengan 2 hektar la han mampu 2 kali panen perbulan dengan perhitungan sawit normal sekali panen mampu menyentuh sekitar1,5 ton dengan harga ditengkulak sawit $1 \mathrm{~kg}$ adalah 1.300, jadi penghasilan petani kelapa sawit sekali panen sekitar $1.300 \times 1.500 \mathrm{~kg}=$ 1.950.000 secara otomatis dalam satu bulan diperoleh sekitar 3.900.000, dapat disimpulkan petani kelapa sawit dilihat dari segi pendapatan lebih menguntungkan dibanding karet. ${ }^{3}$

Pada kehidupan sehari-hari setiap individu maupun masyarakat secara

\footnotetext{
${ }^{2}$ Dwillem, Kalteng.go.id/ogi/viewarticle.asp?ARTICLE_id=96, diakses, 7 November 2016, Pukul 22:56 WIB.

${ }^{3}$ Hasil Observasi dan Wawancara dengan MR, masyarakat Desa Kebun Agung yang melakukan alih fungsi perkebunan, Februari 2018.
} 


\section{Khabib Mustofa}

keseluruhannya akan menghadapi persoalan ekonomi, yaitu persoalan yang menghendaki seseorang untuk membuat keputusan tentang tata cara yang terbaik untuk melakukan suatu kegiatan ekonomi. ${ }^{4}$ Berbagai permasalahan yang timbul di sektor usaha tani karet di Desa Kebun Agung membuat petani mulai berpikir untuk lebih giat dalam bekerja hingga ke arah peralihan fungsi lahan.

Semenjak kedatangan PT. Indoturba dan perusahaan sawit lainnya pola pikir masyarakat mulai berubah, yang mulanya mayoritas petani karet mulai ada perubahan mata pencaharian baru berupa kelapa sawit, perubahan mata pencaharian berhubungan erat dengan perubahan dan dampak pada ekonomi keluarga tersebut. Karena, dalam melakukan berbagai kegiatan ekonomi seorang individu ataupun masyarakat secara keseluruhannya, akan mempunyai beberapa pilihan atau alternatif untuk melakukannya. Berdasarkan alternatif tersebut mereka perlu mengambil keputusan untuk memilih alternatif yang terbaik.

Setiap peralihan kegiatan usaha baik yang terjadi karena faktor yang berasal dari dalam maupun dari luar diri masyarakat akan menghasilkan akibat-akibat yang tidak sama. Adakalanya faktor tersebut hanya mengakibatkan perubahan kecil yang kurang berarti namun dapat juga terjadi perubahan besar dan berarti bagi ekonomi keluarga yang bersangkutan. Oleh karena itu peneliti tertarik mengadakan penelitian untuk mengetahui latar belakang yang menyebabkan petani beralih usaha tani serta dampak ekonomi keluarga tersebut melalui skripsi dengan judul "Dampak Alih Fungsi Perkebunan Karet Ke Kelapa Sawit Bagi Kesejahteraan Petani Desa Kebun Agung Kecamatan Pangkalan Banteng Kabupaten Kotawaringin Barat.

\section{METODE PENELITIAN}

Penelitian ini termasuk kedalam penelitian lapangan atau field research yang artinya penelitian ini dilakukan langsung dilapangan. Pendekatan yang digunakan adalah kualitatif deskriptif yaitu berupa kata tertulis maupun secara lisan dari orang-orang dan pelaku yang diamati. ${ }^{5}$ Dalam konteks penelitian ini, metode deskriptif adalah cara kerja penelitian yang menggambarkan, atau memaparkan keadaan suatu objek secara apa adanya, sesuai dengan

${ }^{4}$ Sadono Sukirno, Mikro Ekonomi: Teori Pengantar, Jakarta: PT. Raja Grafindo Persada, 2006, h. 4.

${ }^{5}$ Lexy J. Moleong,Metodologi Penelitian Kualitatif, Bandung: PT. Remaja Rosdakarya, 2001, h. 6. 


\section{Khabib Mustofa}

situasi dan kondisi pada saat penelitian itu dilakukan. ${ }^{6}$ Dengan metode pengumpulan data melalui wawancara, observasi dan dokumentasi.

\section{PEMBAHASAN}

1. Latar Belakang yang Menyebabkan Alih Fugsi Perkebunan Karet ke Kelapa Sawit

Ciri utama dari masyarakat pedesaan yakni tempat mereka hidup menetap dan berkelompok dimana hampir dari semua anggotanya saling mengenal, termasuk didalamnya hidup dari lahan pertanian, dan usaha-usaha lainnya yang dapat dihasilkan dari hasil alam. ${ }^{7}$ Selain itu mereka memiliki kesatuan dan kekompakkan saling memberi dan menerima informasi khususnya dalam menopang kesejahteraan hidupnya. Sebenarnya, pada awal masyarakat petani desa Kebun Agung menekuni usahanya dibidang perkebunan karet (havea brsiliensis). Adapun yang diambil dari karet adalah getah atau lateksnya, yang oleh masyarkat desa Kebun Agung tanaman merupakan salah satu tanaman yang dikebunkan secara besar-besaran. ${ }^{8}$ Karet merupakan salah satu komoditas perkebunan dengan nilai ekonomis tinggi pada masa itu di desa Kebun Agung. Oleh karena itu tidak salah jika banyak masyarakat yang beranggapan kekayaan yang dimiliki masyarakat petani desa kebun agung khususnya dan juga petani karet Indonesia pada umumnya. praktiknya karet yang diperoleh dari proses pengumpulan getah tanaman karet (lateks) dapat diolah lebih lanjut untuk menghasilkan lembaran karet (sheet), bongkahan (kotak), atau karet remah (crumb rubber) yang merupakan bahan baku industri karet. Tanaman karet dikenal sebagai bahan baku industri, seperti ban, sepatu, dan belt $^{9}$

Namun, sejalan dengan berjalannya waktu ternyata harga karet yang dulunya mampu mensejahterakan masyarakat desa Kebun Agung, acapkali harganya menurun dari harga Rp. 18.000/kg menjadi Rp. 5.600/kg. ${ }^{10}$ Fenomena ini merusak rasa kenyamanan masyarakat desa Kebun Agung yang dulunya merasa sejahtera dengan

\footnotetext{
${ }^{6}$ Ibrahim, Metodologi Penelitian Kualitatif (Panduan Penelitian, Beserta Contoh Proposal Kualitatif), Bandung: ALFABETA, 2015, h. 59.

${ }^{7}$ Syamsir Salam dan Amir Fadhillah, Sosiologi Pedesaan, Jakarta: Lembaga Penelitian Syarif Hidayatullah, 2008, h. 39.

${ }^{8}$ Tim Penulis PS, Panduan Lengkap Karet, Bogor: Penebar Swadaya, 2008, h. 88.

${ }^{9}$ Suwarto dan Yuke Octaviani, 12 Budi Daya Tanaman Perkebunan Unggulan,..., h. 77.

${ }^{10}$ Hasil Wawancara Februari 2018.
} 


\section{Khabib Mustofa}

hasil perkebunan karet yakni yakni merasa aman sentosa dan makmur; selamat (terlepas dari segala macam gangguan) selamat dari himpitan hidup justru masyarakat menjadi kaget dengan fluktuatif harga karet yang menurun tajam tersebut. dan tidak dapat melaksanakan fungsi-fungsi sosialnya secara maksimal. Yaitu membeli sembako, menyekolahkan anak, dan membayar berobat ketika sakit menjadi kendala tersendiri setelah turunnya harga karet.

Melihat pada fenomena anjloknya harga karet kala itu, maka masyarakat desa Kebun Agung berinisiatif ingin merubah budidaya kebun karet menjadi budidaya kelapa sawit. Kelapa sawit yang awalnya dilakukan oleh sebagian kecil masyarakat serta membuahkan hasil yang lebih baik dibandingkan penghasilan kebun karet, maka munculah minat masyarakat lain di desa Kebun Agung tersebut turut serta alih fungsi kebun karet ke Kelapa Sawit.

Kelapa sawit di Indonesia dewasa ini merupakan komoditas primadona. Oleh pemerintah Indonesia mendukung kegiatan perkebunan sawit tersebut bahkan dibuat program plasma untuk mendukung alihfugsi perkebunan sawit tersebut dan saat ini perkebunan rakyat sudah berkembang dengan pesat. Permintaan kelapa sawit disamping digunakan sebagai bahan mentah industri non pangan. Jika dilihat dari biaya produksinya, komoditas kelapa sawit jauh lebih rendah dari pada minyak nabati lainnya. ${ }^{11}$ Selain itu Kelapa sawit mempunyai banyak sekali manfaat. Dalam industri pangan, kelapa sawit dapat digunakan sebagai bahan baku untuk minyak makan, antara lain minyak goreng, margarin, mentega, vanaspati, shortening, dan bahan-bahan untuk membuat kue. Potensi sawit inilah yang memotivasi masyarakat untuk beralih fungsi dari perkebunan karet ke kelapa sawit.

Langkah yang dilakukan oleh petani desa Kebun Agung merupakan upaya melakukan perubahan dalam kehidupan sehari-hari mereka untuk mengatasi persoalan ekonomi mereka agar menjadi lebih baik dari masa sebelumnya. Trauma masa lalu, Petani merasakan adanya persoalan yang meresahkan karena harga karet yang sering turun tajam, sedangkan pekerjaan karet yang mereka tekuni sangat melelahkan karena harus bekerja setiap hari, dengan kondisi yang demikian menurut mereka sangat

\footnotetext{
${ }^{11}$ Suyanto Risza, Seri Budi Daya Kelapa Sawit, Yogyakarta: Penerbit Kanisius, 1994, h. 15.
} 


\section{Khabib Mustofa}

menghambat kesejahteraan keluarga petani menuju ke ekonomi yang lebih baik.

Sebagaimana pemikiran Webber menjelaskan Pemikiran weber menjelasan mengenai proses perubahan sosial dalam masyarakat berkaitan erat dengan perkembangan rasionalitas manusia. Selanjutnya ia menambahkan bentuk rasionalitas manusia meliputi mean (alat) yag menjadi sasaran utama dan ends (tujuan) yang meliputi aspek kultural (budaya), sehingga dapat dinyatakan bahwa pada dasarnya orang besar mampu hidup dengan pola pikir yang rasional yang ada pada seperangkat alat yang dimiliki dan kebudayaan yang mendukung kehidupannya. Orang yang rasional akan memilih alat yang mana yang paling benar untuk mencapai tujuannya. ${ }^{12}$

Mengacu kepada pada pemikiran Webber tersebut jika dihubungkan dengan wilayah dan kondisi domisili masyarakat petani desa Kebun Agung yaitu petani, bibit sawit dan lahan perkebunan adalah rasionalitas alat yang menjadi sasaran utama dalam alih fungsi pekerjaan mereka, karena hal tersebut mereka miliki dan mudah didapatkan. sedangkan tujuannya adalah selain membudidayakan tanaman kelapa sawit juga hasilnya untuk mencapai kesejahteraan perekonomian masyarakat desa Kebun Agung sehingga segala kebutuhan baik sandang, pangan, papan dan peningkatan kualitas hidup seperti menyekolahkan anak ke sekolah yang lebih tinggi.

Lebih lanjut peneliti menguraikan mengapa petani melakukan perubahan alih fungsi usaha kebun karet menjadi kelapa sawit, hal tersebut dilakukan untuk menghindari dampak negatif yang merugikan dari sesuatu pekerjaan perkebunan karet yang harganya terus merosot tajam. Untuk menjabarkan penjelasan lebih lanjut tentang alasan seseorang melakukan perubahan yaitu terdapat dua faktor yang mempengaruhi pertama dari dalam diri dan dari luar masyarakat ${ }^{13}$. Berikut penjelasan kedua faktor petani karet desa Kebun Agung mengalih fungsikan kebun karetnya menjadi kelapa sawit:

\section{a. Faktor dari dalam}

Salah satu poin teori perubahan sosial yang berasal dari dalam adalah penemuan baru. Penemuan baru mengatakan dapat mengubah cara individu dalam bersikap dan

12 Nanang Martono, Sosiologi Perubahan Sosial (Perspektif Klasik Modern, Posmodern, Pokolonial), Jakarta: PT RAJAGRAFINDO PERSADA, 2012, h. 47.

${ }^{13}$ Nanang Martono, Perubahan Sosial, ..., h. 16. 


\section{Khabib Mustofa}

berinteraksi. Konteks yang ada mereka menemukan pekerjaan yang menurutnya lebih mudah dibandingkan dengan karet. Dimana pengerjaan karet mengahabiskan waktu dan tenaga dikarenakan harus berangkat setiap hari, jikalau tidak berangkat untuk dikerjakan maka mereka tidak akan mendapatkan hasil. Karena teknis pengerjaan karet adalah dengan melakukan penyadapan. Penyadapan merupakan salah satu kegiatan pokok dari usaha tani karet, tujuannya untuk membuka pembuluh lateks pada kulit pohon agar lateks tersebut mengalir. ${ }^{14}$ Kegiatan tersebutlah yang petani karet lakukan setiap hari. Sedangkan dengan menjadi petani kelapa sawit mereka hanya perlu waktu menunggu buah panen dengan sendirinya sekitar dua minggu sekali, jadi sisa waktu yang dimiliki bisa untuk pekerjaan lain ataupun santai dengan keluarga.

Kedua, perubahan dari dalam bisa terjadi karena konflik atau pertentangan, maksudnya adalah dalam Nanang Sumartono (2012) hal tersebut terjadi manakala ada perbedaan kepentingan atau terjadi ketimpangan sosial. Sebagaimana diketahui, ketimpangan sosial akan dapat kita temukan dalam setiap masyarakat, hal ini disebabkan setiap individu memiliki kemampuan yang tidak sama dalam meraih sumber daya yang ada, misalnya dalam meraih penghasilan. ${ }^{15}$ Dari hal tersebut yang membuat petani termotivasi untuk menjalani kehidupan yang sama dengan petani yang lebih dari segi ekonomi, agar tidak adanya ketimpangan dibidang pendapatan ekonomi, oleh karena itu agar ekonomi petani desa Kebun Agung berusaha untuk sejajar dengan para petani yang lebih awal alih fungsi perkebunan dari karet ke kelapa sawit untuk memenuhi kehidupan mereka. Alih fungsi dari karet ke kelapa sawit tersebut disebabkan pendapatan karet kurang untuk memenuhi kesejahteraan keluarga. Hal tersebut yang menurut peneliti menjadi latar belakang mengapa petani karet mengalihfungsikan lahannya menjadi kelapa sawit. Karena pendapatan peranannya sangat penting terhadap kesejahteraan keluarga.

Jadi, hemat peneliti faktor dari dalam yang menyebabkan petani karet mengalihfungsikan kebun karetnya menjadi kelapa sawit yaitu karena petani merasa lelah sebab teknis pekerjaan petani karet yang harus dikerjakan setiap hari, berbeda

\footnotetext{
${ }^{14}$ Yuke Octaviani, dan Suwarto,12 Budi Daya Tanaman Perkebunan Unggulan (Cengkih, Cokelat, Kapas, Karet, Kelapa, Kelapa Sawit, Kopi, Lada, Tebu, Tembakau, Teh, dan Vanili), Bogor: Penebar Swadaya, 2012, h. 2.

${ }^{15}$ Nanang Martono, Sosiologi Perubahan Sosial..., h. 16
} 


\section{Khabib Mustofa}

dengan kelapa sawit yang hanya menunggu waktu buah panen sekitar dua minggu sekali. Kedua, karena ada motivasi dari petani yang ingin mengangkat ekonomi keluarga, dengan menjadi petani kelapa sawit pendapatan mereka menjadi lebih banyak dan lebih mempunyai banyak waktu untuk keluarga ataupun untuk usaha lainya.

\section{b. Faktor dari luar}

Selanjutnya faktor dari luar, merupakan perubahan yang terjadi karena adanya kondisi lingkungan fisik. Kondisi lingkungan fisik ini terkadang memaksa masyarakat untuk meninggalkan kebiasaan yang lama. ${ }^{16}$ Hal tersebut terjadi pada petani karet desa Kebun Agung yaitu karena faktor lahan, pengalaman yang ada lahan yang apabila setelah dari karet, kemudian ditanami kembali ke karet maka tidak akan maksimal lagi hasilnya nanti. Kemudian, harga karet yang tidak stabil membuat mereka resah, bahkan ketika anjlok menurut mereka untuk kembali ke harga semula membutuhkan waktu yang lama.

Selain hal tersebut faktor perubahan yang berasal dari luar bisa juga terjadi karena pengaruh masyarakat/kebudayaan/ kebiasaan lain. ${ }^{17}$ Hal ini juga yang terjadi pada petani karet di Desa Kebun Agung, alasan mereka mengalihfungsikan kebun karetnya yakni karena melihat dan mengamati petani kelapa sawit lainnya dan mereka menyimpulkan menjadi petani kelapa sawit lebih ringan pekerjaannya dan lebih penghasilannya. Selain hal itu, secara letak geografis letak desa Kebun Agung yang berdekatan dengan perusahaan Astra Agro Lestari dan perusahaan sawit lainnya sedikit banyak berpengaruh kepada wawasan mereka tentang pertanian. Bahkan, beberapa petani mengikuti pelatihan di perusahaan sawit terdekat. Kemudian, ada yang berlatar belakang bekerja di perusahaan sawit PT. Astra Agro Lestari, kemudian mengarahkan alih fungsi kebun karetnya menjadi kelapa sawit.

Kehidupan seorang petani tidaklah statis, melainkan mengalami perubahan seiring dengan terjadinya perubahan dan kemajuan zaman. Proses alih fungsi dari kebun karet menjadi kelapa sawit tidaklah lepas dari pilihan rasional petani. Teori pilihan rasional mengatakan pada dasarnya orang besar mampu hidup dengan pola pikir yang rasional yang ada pada seperangkat alat yang dimiliki dan kebudayaan yang mendukung

\footnotetext{
${ }^{16}$ Nanang Martono, Sosiologi Perubahan Sosial, ...h. 16

${ }^{17}$ Ibid., h. 17.
} 


\section{Khabib Mustofa}

kehidupannya. Orang yang rasional akan memilih alat yang mana yang paling benar untuk mencapai tujuannya. ${ }^{18}$ Petani karet memilih alat alih fungsi menjadi petani kelapa sawit guna mencapai tujuannya mensejahterakan keluarganya. Karena dari penjelasan diatas dari segi teknis kerja lebih mudah dan nyaman di kelapa sawit, dari segi pendapatan lebih banyak, terakhir faktor harga sawit yang lebih stabil, tidak membuat resah petani. Dari hal-hal tersebutlah munculah pilihan rasional petani mengalihfungsikan kebun karetnya menjadi kelapa sawit untuk tujuan peningkatan ekonomi dan kesejahateraan keluarga.

Selanjutnya cara mereka mengalihfungsikan kebun karetnya menjadi kelapa sawit. Kelapa sawit dalam proses menunggu panennya sekitar 3 tahun setengah baru bisa panen, sudah barang tentu bagi mereka yang hanya mengandalkan kebun karet sebagai mata pencaharian apabila lahan tersebut dialihkan fungsikan mereka tidak punya pekerjaan selama 3 tahun tersebut. jadi, cara mereka yaitu dengan cara kebun karet yang mereka miliki tidak dirubah kesemuannya namun dengan proses, sedikitsedikit semisal dari 4 hektar lahan kebun karet maka 2 hektar dahulu yang mereka alih fungsikan menjadi kelapa sawit dengan hal tersebut mereka masih punya mata pencaharian. Namun, ada sebagian dari mereka yang mempunyai pekerjaan lain seperti pedagang dan bekerja di perusahaan.

Para ekonom membagi perubahan ekonomi dalam empat kelompok yakni perubahan musiman, perubahan baru, perubahan yang terarah dan perubahan berkala. Jika dilihat perubahan yang terjadi di desa Kebun Agung dengan masyarakat yang mengalihfungsikan kebun karetnya menjadi kelapa sawit yakni termasuk kedalam perubahan baru dan perubahan berkala. Perubahan baru merupakan perubahan yang tidak teratur dan muncul karena peristiwa yang baru seperti faktor alam maupun sosial. ${ }^{19}$ Faktor alam yang terjadi karena menurut pengalaman mereka lahan karet apabila ditanami karet kembali maka panen selanjutnya tidak akan maksimal. Sedangkan faktor sosial karena adanya pengaruh dari petani kelapa sawit yang petani karet lihat lebih

${ }^{18}$ Dwi Prasetya, Dampak Alih Fungsi Lahan dari Sawah Ke Tambak Terhadap Mata Pencaharian Masyarakat Desa( Studi Kasus di Desa Cebolek Kidul Kecamatan Margoyoso Kabupaten Pati), Skripsi, Semarang: Universitas Negeri Semarang, 2015, h. 14

${ }^{19}$ Jaribah bin Ahmad Al-Haritsi, Fiqh Ekonomi Umar bin Al-Khatab, Jakarta Timur: Khalifa. 2006. h. 352 . 


\section{Khabib Mustofa}

sukses dari mereka sehingga ingin diikuti jejaknya dan juga faktor berdekatan dengan perusahan kelapa sawit membuat petani karet desa kebun sering berinteraksi dengan karyawan pabriknya ataupun buruh panen perusahaan tersebut yang membuat ketertarikan mengalihfungsikan lahan karetnya menjadi kelapa sawit muncul.

\section{Dampak Alih Fungsi Perkebunan Karet ke Kelapa Sawit bagi Kesejahteraan Petani} Desa Kebun Agung

Berangkat dari permasalahan-permasalaan ekonomi manusia memiliki keinginan yang tidak terbatas namun memiliki sumber daya untuk memenuhi kebutuhan tersebut memiliki batas. Oleh sebab itu, manusia perlu melakukan pilihan agar sumber daya tersebut dapat memenuhi keinginannya. ${ }^{20}$ Ketika melakukan pilihan sudah barang tentu mempunyai dampak yang dirasakan setelahnya baik positif ataupun negatif. Dampak merupakan sebab melakukan sesuatu yang mendatangkan akibat baik positif ataupun negatif. Lebih lanjut Zanuar Ajasi mengatakan bahwa dampak merupakan pengaruh ataupun akibat yang timbul melalui dalam setiap pengambilan keputusan yang diambil oleh seseorang, dampak sendiri ada yang sesuai dengan harapan ada kalanya tidak. ${ }^{21}$ Dampak dalam penelitian ini adalah akibat dari petani mengalihfungsikan kebun karetnya menjadi kelapa sawit bagi kesejahteraan petani di desa Kebun Agung.

Setiap keluarga pasti mengharapkan yang terbaik bagi keluarganya. Segala usaha akan dilakukan agar kehidupan ekoomi keluarganya baik dan sejahtera. Salah satu usaha petani desa Kebun Agung yakni dengan mengalihfungsikan kebun karetnya menjadi kelapa sawit dengan harapan setelah beralih fungsi tersebut keluarga lebih baik dan sejahtera.

Kesejahteraan sendiri merupakan kondisi agregat dari kepuasan individidu, menurut Undang-Undang Nomor 11 Tahun 2009 kesejahteraan didefinisikan sebagai kondisi terpenuhinya kebutuhan material, sepiritual, dan sosial warga negara agar dapat hidup layak dan mampu mengembangan diri sehingga dapat melaksanakan fungsi

${ }^{20}$ Dewan Pengurus Nasional FORDEBI \& ADESY, Ekonomi dan Bisnis Islam (Seri Konsep dan Aplikasi Ekonomi dan Bisnis Islam).

${ }^{21}$ Zanuar Ajasi, Dampak Sosio-Ekonomi Keberadaan Psk (Kajian Sosiologis Terhadap Keberadaan PSK di Gang Sadar Batubara), Skripsi, Purwokerto: Institut Agama Islam Negeri Purwokerto, 2016, h. 10. 


\section{Khabib Mustofa}

sosialnya.

Terdapat beberapa dampak yang dirasakan setelah petani mengalihfungsikan kebun karetnya menjadi kelapa sawit di desa Kebun Agung. Diantaranya sebagai berikut:

\section{a. Peningkatan Pendapatan}

Dalam rangka mencapai kesejahteraan yang lebih baik salah satu instrumen yang penting untuk mewujudkannya adalah melalui pendapatan yang sesuai. Pendapatan merupakan sesuatu keseluruhan penerimaan yang diterima petani dari hasil penjualan tanaman yang dimiliki. ${ }^{22}$ Jika dilihat berdasarkan pengertian diatas pendapatan petani disini dikategorikan kepada pendapatan yang berasal dari jasa faktor produksi yakni berupa hasil yang diperoleh dari upaya mereka mengusahakan usaha tani milik mereka sendiri. Pendapatan petani karet sendiri berasal dari getah/lateks yang diperoleh melalui disadap kemudian dikumpulkan dalam satu bongkahan dan dijual. Sedangkan pendapatan kelapa sawit berasal dari yakni tandan buah segar yang dihasilkan kemudian dikalikan dengan harga buah sawit perkilogramnya.

Berdasarkan data yang diperoleh dengan para subjek penelitian ini, mereka mengatakan adanya peningkatan terhadap pendapatan keluarga setelah mereka melakukan alih fungsi kebun karetnya menjadi kelapa sawit. Lebih jelasnya perhatikan tabel dibawah ini:

Tabel. 1

Subjek petani dan golongan pendapatan sebelum dan setelah alih fungsi kebun karet ke kelapa sawit

\begin{tabular}{|l|l|l|l|l|}
\hline \multirow{2}{*}{ Subjek } & \multicolumn{2}{|l|}{ Karet } & \multicolumn{2}{l|}{ Kelapa Sawit } \\
\cline { 2 - 5 } & pendapatan & Kategori & Pendapatan & kategori \\
\hline WI & 4 Juta & ST & 5 Juta & ST \\
\hline MR & 4 Juta & ST & 6-7Juta & ST \\
\hline SU & 3 Juta & T & 5-6 Juta & ST \\
\hline TR & 2 Juta & S & 4 Juta & ST \\
\hline
\end{tabular}

${ }^{22}$ Eeng Ahman, Membina Kompetensi Ekonomi (Untuk Kelas X Sekolah Menengah Atas/ Madrasah Aliyah), Bandung: Grafindo Media Pertama, 2007 h, 78. 


\section{Khabib Mustofa}

\begin{tabular}{|l|l|l|l|l|}
\hline NO & 2 Juta & S & 4 Juta & ST \\
\hline AS & 2 Juta & S & 3 Juta & T \\
\hline SA & 2 Juta & S & 3 Juta & T \\
\hline NN & 1.5 Juta & R & 2 Juta & S \\
\hline NG & 1 Juta & R & 1.5 Juta & R \\
\hline
\end{tabular}

Keterangan: ST :(Sangat Tinggi), T: (Tinggi), S: (Sedang), R: (Rendah).

Mengacu pada Tabel. VIII yang sebelumnya peneliti paparkan pada penyajian data bahwa paling sedikit dari mereka mengalami kenaikan pendapatan sebesar Rp. 500. 000-, sedangkan paling banyak mencapai Rp. 2.000 .000 bahkan lebih, seperti yang dialami oleh responden TR dari yang sebelumnya pendapatan perbulan berkisar Rp. 2.000.000 setelah alih fungsi meningkat menjadi Rp. 4.000.000, juga yang dialami responden MR dan SU dari yang semula pendapatan berkisar Rp. 3.000.000 setelah alih fungsi meningkat menjadi 5 sampai 6 juta rupiah per bulannya.

Data tersebut diperoleh langsung melalui wawancara dengan subjek penelitian ini, mereka menjelaskan merasakan sendiri peningkatan pendapatan. Mereka yang berependapatan masih dibawah dengan yang lainnya karena baru saja mengalihfungsikan kebun karetnya dalam artian masih ada sebagian pohon yang belum berbuah normal. Sedangkan mereka yang berpenghasilan tinggi adalah mereka yang sudah lama dan sudah normal hasil panennya.

Berdasarkan data yang telah peneliti analisis diatas ada terjadinya peningkatan pendapatan setelah mereka mengalihfungsikan kebun karetnya menjadi kelapa sawit. Tidak hanya disitu, jika dikaitkan dengan klasifikasi golongan pendapatan menurut Badan Pusat Statistik semuanya berpindah golongan, kategori sangat tinggi terdapat 5 subjek, kategori tinggi terdapat 2 subjek, 2 sisanya masuk golongan sedang.

Pendapatan merupakan poin penting dalam ekonomi dan kesejahteraan keluarga. Dengan adanya peningkatan pendapatan tersebut subjek lebih mudah untuk memenuhi kebutuhan sehari-hari, keperluan anak, dan berbagai hal-hal lain yang 


\section{Khabib Mustofa}

dapat meningkatkan kondisi ekonomi dan kesejahteraan keluarga tersebut.

\section{b. Memperingan Pekerjaan}

Dampak selanjutnya yang dirasakan dari alih fungsi karet menjadi kelapa sawit yakni ringannya pekerjaan. Ada beberapa keringanan yang dirasakan pertama karena karet yang diambil hasilnya adalah getah/latek dari kulit pohonnya tersebut memaksa mereka harus berangkat setiap hari karena jikalau tidak dikerjakan makan tidak akan mendapatkan hasil, belum lagi jika kondisi hujan maka tidak bisa dikerjakan karena kondisi pohon yang basah membuat getah yang mengalir ke tempat penampungan akan terganggu. Berbeda dengan kelapa sawit, teknis pekerjaan kelapa sawit yaitu ketika sudah panen normal maka cukup dengan dua minggu sekali untuk menuai hasil atau panen. Kedua, teknis penjualan hasil panen karet yaitu petani sendiri yang mengantar ke tengkulak. Berbeda dengan kelapa sawit meskipun sangat banyak namun tengkulak sendiri yang menjemput atau mengambil di kebun petani tersebut.

Dengan lebih banyaknya waktu senggang menjadi petani kelapa sawit memudahkan mereka untuk bisa melakukan kegiatan usaha produktif lainnya. Semisal yang dilakukan beberapa dari mereka dengan usaha toko sembako, hingga membuka usaha kolam ikannya. Selain hal tersebut dengan adanya waktu membuat mereka mampu berpartisipasi dan memenuhi kebutuhan sosialnya. Karena pada dasarnya kesejahteraan adalah mereka yang tidak hanya mampu memenuhi kebutuhan hidupnya tapi juga mereka yang mampu dan memiliki hubungan yang serasi, selaras dan seimbang antar anggota keluarga dan dengan masyarakat juga lingkungan. ${ }^{23}$ Dengan kemudahan dan lebih banyaknya waktu menjadi petani kelapa sawit dibanding dengan petani karet membuat petani lebih mudah dalam memenuhi kesejahteraan keluarganya baik.

\section{c. Bertambahnya Aset}

Tidak hanya pendapatan dan ringannya pekerjaan dampak yang dirasakan petani karet setelah alihfungsi kebun karet menjadi kelapa sawit. Dampak yang petani rasakan adanya peningkatan aset yang mereka miliki, aset adalah sumber daya yang

\footnotetext{
${ }^{23}$ Lihat Undang-Undang Republik Indonesia NO 11 Tahun 2009 Tentang Kesejahteraan Sosial.
} 


\section{Khabib Mustofa}

dikuasai sebagai akibat dari peristiwa masa lalu, dari sanalah manfaat ekonomi masa depan diharapkan mengalir dan pada dasarnya aset adalah sesuatu yang dimiliki. Aset merepresentasikan segala sesuatu yang menghasilkan keuntungan, modal, dan arus kas yang bernilai dan dan dapat dikonversi menjadi uang untuk memenuhi kewajiban. ${ }^{24}$ Peningkatan aset yang dirasakan mulai dari mempunyai tabungan. Tabungan merupakan simpanan berbentuk uang ataupun non-uang yang mempunyai nilai yang fungsinya sebagai jaga-jaga untuk keperluan dimasa yang akan datang. Dengan mereka mempunyai tabungan yang lebih sudah barang tentu kehidupan mereka lebih merasa aman karena mempunyai dana darurat untuk jaga-jaga apabila terjadi sesuatu. Selain hal tersebut tabungan juga bisa sebagai persiapan keperluan tertentu dimasa yang akan datang.

Selanjutnya, rumah yang lebih baik, rumah merupakan kebutuhan primer tempat bernaung. Apabila seseorang merasa nyaman dan aman dengan rumahnya maka keluarga akan lebih sejahtera. Karena kesejahteraan sendiri merupakan kondisi terpernuhinya kebutuhan material juga perasaan selamat, aman dan tenteram.

Bertambahnya aset yang selanjutnya yakni berupa barang atau benda yang dimiliki semisal yang dirasakan hingga mampu mempunyai mobil pribadi. Dengan adanya mobil tersebut membuat mereka lebih mudah memenuhi kebutuhan material dan spiritualnya. Selain hal tersebut mereka juga lebih mudah untuk memenuhi kebutuhan sosialnya semisal untuk keperluan perjalanan keluarga ataupun untuk masyarakat sekitar. ${ }^{25}$ Selain hal diatas pertambahan aset yang dirasakan adalah memulai usaha yang lain, yaitu dengan menggeluti usaha baru berupa tambak ikan. Dengan bertambahnya usaha sudah barang tentu nantinya pendapatan keluarga akan meningkat. Pendapatan memiliki peran penting dalam ekonomi dan kesejahteraan keluarga. ${ }^{26}$ Dengan pertambahan aset yang telah dijelaskan diatas kebutuhan baik primer maupun sekunder yang mereka perlukan akan lebih tercukupi. Dengan merasa seperti itu merepresentasikan kesejahteraan akan lebih dirasakan.

\section{d. Keluarga Sejahtera}

${ }^{24}$ Jessica Diana Kartika dan Rudyant Siswanto Wijaya, Logo: Visual asset Development, Jakarta: PT. Elec Media Komputindo, 2004, h. 12.

25 Wawancara dengan MR.

${ }^{26}$ Wawancara dengan SA. 


\section{Khabib Mustofa}

Kesejahteraan merupakan hal atau keadaan sejahtera; aman, selamat, tenteram. ${ }^{27}$ Bisa dikatakan kondisi sejahtera ketika seseorang tersebut merasa selamat, aman, dan tentram. Undang-Undang Republik Indonesia Nomor 11 Tahun 2009 Tentang Kesejahteraan Sosial menjelaskan kesejahteraan sosial merupakan kondisi terpenuhinya kebutuhan material, spiritual, dan sosial warga negara agar dapat hidup layak dan mampu mengembangkan diri, sehingga dapat melaksanakan fungsi sosialnya. ${ }^{28}$ Terdapat beberapa Indikator keluarga sejahtera dalam BKKBN , namun peneliti memilih beberapa alatnya untuk melihat subjek termasuk kedalam kategori keluarga sejahtera diantaranya tentang pendidikan, pakaian, tabungan, dan keaktifan di kegiatan kemasyarakatan.

Hasilnya, selain mereka lebih mampu untuk memenuhi kebutuhan pangan hidupnya, juga lebih mampu untuk memenuhi kebutuhan sandang atau pakaian bahkan mampu untuk membeli yang baru di setiap tahunnya. Kemudian, kebutuhan pendidikan anak-anak juga mereka penuhi dengan menyekolahkannya di lembaga pendidikan pilihan keluarga atau anak itu sendiri. Selain hal tersebut 7 (tujuh) dari (9) responden dalam penelitian ini mampu untuk menyisihkan hasil usaha mereka untuk ditabung yang mana sebelum mereka alih fungsi dari kebun karet ke kelapa sawit mereka belum mampu menyisihkan penghasilannya untuk ditabung. Bahkan, sebagian dari anggota keluarga mereka mampu untuk aktif di kegiatan kemasyarakatan di desa Kebun Agung. Seperti istri yang aktif dikegiatan ibu-ibu seperti pkk hingga ada yang menjadi imam/pengurus masjid. Dengan aktifnya mereka di kegiatan masyarakat membuktikan bahwa telah sesuai dengan kesejahteraan sosial menurut Undang-undang Nomor 11 Tahun 2009 tentang kesejahteraan sosial yang mengatakan bahwa kondisi sejahtera yaitu mampu memenuhi kebutuhan material, hidup dengan layak, mampu mengambangkan diri dan dapat melaksanakan fungsi sosialnya.

Jadi, dampak yang dirasakan petani setelah alih fungsi dari kebun karet ke kelapa sawit yaitu berdampak positif bagi kesejahteraan keluarga petani tersebut. Mayoritas mereka

\footnotetext{
${ }^{27}$ https://kbbi.web.id/sejahtera

${ }^{28}$ Lihat Undang-Undang Republik Indonesia Nomor 11 Tahun 2009 Tentang Kesejahteraan

Sosial
} 


\section{Khabib Mustofa}

mampu memenuhi kebutuhan dasar rumah tangga, seperti halnya kebutuhan pangan, sandang, dan kebutuhan anak-anak, tidak hanya sampai disitu sebagian petani juga mampu memenuhi kebutuhan sosial dan kemasyarakatan dalam artian mampu berperan aktif dikegiatan sosial dan kemasyarakatan. Karena kesejahteraan tidak hanya kebutuhan hidup yang terpenuhi namun juga hubungan yang serasi, seimbang, selaras antar anggota keluarga juga dengan masyarakat dan lingkungan

\section{PENUTUP}

Latar belakang penyebab petani karet beralih fungsi menjadi petani kelapa sawit di desa Kebun Agung Kecamatan Pangkalan Banteng Kabupaten Kotawaringin Barat adalah pekerjaan sebagai petani karet yang dilakukan setiap hari sedangkan harganya murah sehingga pendapatan petani tidak cukup untuk memenuhi kebutuhan ekonomi. Sedangkan pekerjaan kelapa sawit hanya dua minggu sekali harganya lebih mahal dibandingkan karet dan cukup untuk memenuhi kebutuhan sehari-hari. Dampak kesejahteraan keluarga petani karet setelah alih fungsi menjadi petani kelapa sawit Desa Kebun Agung Kecamatan Pangkalan Banteng Kabupaten Kotawaringin Barat adalah berdamapak positif bagi petani, pendapatan mereka meningkat, pekerjaan lebih ringan, adanya peningkatan aset yang dimiliki, dan keluarga lebih merasa sejahtera dari sebelumnya.

\section{DAFTAR PUSTAKA}

Al-Haritsi, Jaribah bin Ahmad, Fiqh Ekonomi Umar bin Al-Khatab, Jakarta Timur: Khalifa. 2006.

Ahman, Eeng, Membina Kompetensi Ekonomi (Untuk Kelas X Sekolah Menengah Atas/ Madrasah Aliyah), Bandung: Grafindo Media Pertama, 2007.

Dwillem, Kalteng.go.id/ogi/viewarticle.asp?ARTICLE_id=96, diakses, 7 November 2018, Pukul 22:56 WIB.

Dewan Pengurus Nasional FORDEBI \& ADESY, Ekonomi dan Bisnis Islam (Seri Konsep dan Aplikasi Ekonomi dan Bisnis Islam).

Ibrahim, Metodologi Penelitian Kualitatif (Panduan Penelitian, Beserta Contoh Proposal Kualitatif), Bandung: ALFABETA, 2015, h. 59.

https://kbbi.web.id/sejahtera

Kartika, Jessica Diana dan Rudyant Siswanto Wijaya, Logo: Visual asset Development, Jakarta: PT. Elec Media Komputindo, 2004 
Martono, Nanang, Sosiologi Perubahan Sosial (Perspektif Klasik Modern, Posmodern, Pokolonial), Jakarta: PT RAJAGRAFINDO PERSADA, 2012, h. 47.

Moleong, Lexy J. Metodologi Penelitian Kualitatif, Bandung: PT. Remaja Rosdakarya, 2001.

Octaviani, Yuke dan Suwarto,12 Budi Daya Tanaman Perkebunan Unggulan (Cengkih, Cokelat, Kapas, Karet, Kelapa, Kelapa Sawit, Kopi, Lada, Tebu, Tembakau, Teh, dan Vanili), Bogor: Penebar Swadaya, 2012.

Prasetya, Dwi, Dampak Alih Fungsi Lahan dari Sawah Ke Tambak Terhadap Mata Pencaharian Masyarakat Desa( Studi Kasus di Desa Cebolek Kidul Kecamatan Margoyoso Kabupaten Pati), Skripsi, Semarang: Universitas Negeri Semarang, 2015.

Risza, Suyanto, Seri Budi Daya Kelapa Sawit, Yogyakarta: Penerbit Kanisius, 1994.

Salam, Syamsir dan Amir Fadhillah, Sosiologi Pedesaan, Jakarta: Lembaga Penelitian Syarif Hidayatullah, 2008, h. 39Tim Penulis PS, Panduan Lengkap Karet, Bogor: Penebar Swadaya, 2008, h. 88

Tempo.Com 21 September 2007.

Undang-Undang Republik Indonesia Nomor 11 Tahun 2009 Tentang Kesejahteraan Sosial

Zanuar Ajasi, Dampak Sosio-Ekonomi Keberadaan Psk (Kajian Sosiologis Terhadap Keberadaan PSK di Gang Sadar Batubara), Skripsi, Purwokerto: Institut Agama Islam Negeri Purwokerto, 2016. 